\title{
Using System Dynamics Approach in Modeling the Integrated Farming Scenario to Increase Cassava Production in Indonesia
}

\author{
Bambang Yudi Ariadi \\ Dept. of Agribusiness \\ Universitas Muhammadiyah Malang \\ Malang, Indonesia \\ Dini Rochdiani \\ Dept.of Agricultural Economics \\ Universitas Padjajaran \\ Bandung, Indonesia
}

\author{
Maman Haeruman Karmana \\ Dept. of Agricultural Economics \\ Universitas Padjajaran \\ Bandung, Indonesia \\ Elly Rasmikayati \\ Dept. of Agricultural Economics \\ Universitas Padjajaran \\ Bandung, Indonesia
}

\begin{abstract}
This research was focused on integrated farming system and usage of system dynamic approach. This research was done in Trenggalek District, East Java Province, Indonesia. It used secondary data, and supported by primary one. Modeling and making policy scenario used system dynamics approach. The model fit was examined by Theil test. Modeling with system dynamics approach is effective to create a complex model of IFS, because the model behavior is similar with those of the real-world. The model also could be used to simulate policy scenarios and estimate the future performance of the model. The scenario done was a policy of technology innovation namely optimal production with the environmental awareness. This scenario focuses on using organic fertilizer in cassavagoats integrated farming; it is quite effective and can decrease farming cost as much as $27.75 \%$ up to $34.36 \%$. The scenario needs introduction of composting technology and availability of the facilities and infrastructure. Therefore, the implementation needs supports from stakeholder, i.e. government and society, as well as public and private sectors.
\end{abstract}

\section{General Terms}

Modeling, integrated farming system (IFS), agribusiness.

\section{Keywords}

System dynamics, modeling, scenario, cassava, agribusiness, organic fertilizer.

\section{INTRODUCTION}

Cassava is one of important food crops in Indonesia. It is not only easy to grow but also can substitute rice and maize as source of carbohydrate. That is why cassava spread to almost the entire territory of Indonesia. One of the important production center in East Java Province is Trenggalek District.

Cassava is a regionally important crop in Trenggalek District, it is marketed in fresh and processed forms (Ariadi et al, 2014). Processed cassava is marketed in the form of ready food and half-in-processed products. The ready foods are in the form of chips, crackers, biscuit and several traditional snacks, they are marketed more locally. Meanwhile, the halfin-processed products are marketed as dried cassava, chips (raw material of flour), flour and starch. They are marketed widely and some of them are exported.
Cassava agribusiness involves thousands of people in Trenggalek. They are farmers, processors and also marketers. That is why an effective policy in developing cassava agribusiness must be designed comprehensively based on an empirical study.

Some previous studies used system dynamics approach to analyze a complex system. Some of them were applied on agricultural system, such as: dynamic model of farm management (Ariadi et al. 2014); eco-agriculture system (Li et al. 2012); organic farming in Slovenia (Paz \& Kljajic 2013); integrated pig production supply chain (Piewthongngam \& Vijitnopparat 2014). System dynamics modeling was also applied on the integrated assessment of sustainable marine cage culture (Château et al. 2015).

Some scientific policy scenario also used system dynamics. The policy scenarios were applied on the sustainable development of ecological agriculture in China (Shi \& Gill 2005); eco-agriculture system with policy recommendations ( $\mathrm{Li}$ et al. 2012); future biodiesel policy designs and consumption patterns in Latvia (Barisa et al. 2015).

Other research on integrated, conventional and sustainable agribusiness used multinomial logit regression (Anim and Mandleni 2011). The result informs that the integrated agribusiness system is the most appropriate system in the developing region that is dominated by less-educated farmers and lower information access. This research developed IFS as a tool in developing cassava agribusiness, but the difference is using dynamics perspective.

Some previous researches have similarities and differences with this research. System dynamics also has been used to analyze food availability in East Java, the result showed that sweet potato and cassava are future prospective commodity that can substitute rice (Rahmatullah et al, 2012). The similarities are cassava as the research objective and the system dynamics approach. The difference, however, this research studied the cassava production in the IFS.

Other research used descriptive approach in developing institutional model to increase production and farmers income, based on integrated livestock and rice crops (Rachman. et al., 2009). This research was focused on cassava crops as the main commodity and used the system dynamics approach as the main analysis. 
Prospect of integrated farming system which was applied on small farmer families with marginal land has been done in Bangladesh (Mamun et al., 2011). It gives a philosophical and practical foundation about the implementation of IFS on small farmer and marginal land in Trenggalek District, East Java. Again, the difference of this research is usage of system dynamics approach.

An effective policy of cassava marketing has an important contribution to the sustainable agriculture in Nigeria, both for domestic and international market (Awoyinka, 2009). Similarity of this research is case study of cassava marketing. Meanwhile, the difference is the perspective of system dynamics.

Food consumption analysis at society level showed an improvement of public welfare (Ariani, 2010). This research used a same normative basis of welfare achievement, food diversification. The difference is this research describes simulation of organic fertilizer usage to increase cassava production by using of system dynamics approach.

Research about cassava leaves and forage crops for ruminant feed in the establishment of sustainable cassava farming system in Indonesia used a descriptive approach (Wargiono et al, 2002). This research focused on the same plant, cassava, but it used a system dynamic as the modeling basis.

Study on the structure and determinants of land-use intensity among food crop farmers in Southwestern Nigeria found that the human is an important component in agricultural system and significantly affects land-use intensity for food crops (Olaide, 2011). It was inspiring to design the important structure of IFS, however, this research used the different perspective, modeling with system dynamics.

Using system dynamics simulation helps the micro enterprise to market the leather crafts more effective and efficient (Sari et al., 2010). Similarity of this research is using of system dynamics simulation, but it was applied on production subsystem of cassava-goat IFS.

System dynamics modeling was able to reveal the predictions of demand for energy in the future (Sterman, 1998) This research also used the system dynamics, however, it was aimed to reveal the prediction of cassava production for the next 20 years.

Systems thinking approach to examine the behavior of a dynamic organization through self learning using feedback mechanisms (Senge and Sterman, 1992). This research also used system thinking approach to study model component in developing agribusiness of cassava through IFS.

This research was focused on IFS and usage of system dynamic approach. The overall model consists of three submodels (sub-system): farm production, distribution, and consumption. Previous researches related the three subsystems of agribusiness were analyzed partially. This research analyzed the three sub-systems simultaneously in one model by using system dynamics approach. Finding of this research offers a problem solution in developing cassava agribusiness with the IFS. This paper presents the first sub-model, farm production, focusing on the cassava-goat IFS.

The next part of this paper is organized as follows: Section 2 provides a summary of the theory of system dynamics and integrated farming system. Section 3 contains research design, data collection, data analysis and model validation. Section 4 presents the result of modeling with system dynamics, and Section 5 concludes the study.

\section{LITERATURE REVIEW}

\subsection{System Dynamics Approach}

IFS model to develop cassava agribusiness is a complex and dynamic phenomena, because the behavior is not only caused by partially and linear factors but also the interaction between components and the environment that are interdependent as a system. Beside, agribusiness system itself has a goal to reach a better performance. The effort to reach the goal causes dynamics; a continuous changing needs to develop and control. Therefore, study on the complex and dynamic agribusiness phenomena needs a system thinking and paradigm.

System dynamics is a method to analyze the closed-loop system, in which interdependent components interact and change dynamically (Sterman 1991; Williams \& Harris 2005).

Sterman (1991) stated some principles should be mentioned in dynamics model ie: a) ideal condition different with the actual one; b) there is stock and flow structure of the real world; c) different flow for the different concept; d) involves only the available information from actors in the system; e) the structure making decision should be appropriate with the managerial practical; f) should be robust in an extreme condition.

System dynamics method is supported by computer software to solve a complex problem, focussing on analysis and policy design (Sterman, 2000). It is closely related with numerous system dynamics, namely behavioral pattern of the system in the moving time (Angerhofer et al, 2000). An important aim of using system dynamics is to obtain a qualified design that is comparable with the actual information.

\subsection{Integrated Farming System}

In recent years, concept of integrated farming system (IFS) is becoming more varied and complex. Agbonlabor et al in their study in Nigeria definited IFS as a mixed farming system that integrate crops and livestock (Agbonlabor et al, 2003). Meanwhile Okigbo stated that IFS involves at least two separate parts of crops and livestock, however, they are logically interdependent (Okigbo, 1995).

More specific and technical, Radhammani explained that IFS is an agricultural system that minimize risk, increase yield and income, by using organic waste from crops and animals (Radhammani et al, 2003). Similarly, IFS is an agricultural system with biological recycling between farming, fishery and livestock (Yuhono, 2007). More detail, vertical IFS differs with the horizontal one. Vertical integration is an integration of one ownership where one product becomes the input of the other product, meanwhile horizontal integration is managing the same commodity together among some ownership.

Some IFS application showed a better performance of yield and profit. IFS of fruits crops and goat on vertisol soil in Tamil Nadu, India, showed bruto income, cost, net profit, extra income, and work opportunity for small and marginal farmer (Senthilvel et al. 1998). Moreover, IFS bases on vegetables, tree, livestock and fish showed more yield and income, better soil fertility and environment, comparing with the commercial farming system based on rice as single commodity (Mamun et al, 2011). 


\section{METHODOLOGY}

\subsection{Research Design}

This study was designed to solve a complex problem by using system dynamics approach. It could be used to analyze the structure of a system and to conduct simulation to generate scenario to improve performance of the system. In ontological, epistemological and axiological modeling with system dynamics is objective, subjective and consider the values of the actor (Pruyt, 2006). Objectivity is reached because the basic model of system dynamics exists in the real world, meanwhile subjectivity happens because at a certain stage it requires involvement of researchers in the modeling process. Other similar opinions stated that: the ontological principle of system dynamics is the system that exists in the real world and its structure must be explained (Paucar-Caceres \& Rodriguez-Ulloa, 2006); epistemological principles of system dynamics in assuming positivism is to explain the structure of the real world with the rate and flow (Lane \& Schwaninger, 2008); in the paradigm of post-positivism, researcher and reality of the object studied cannot be separated (Muslih, 2008).

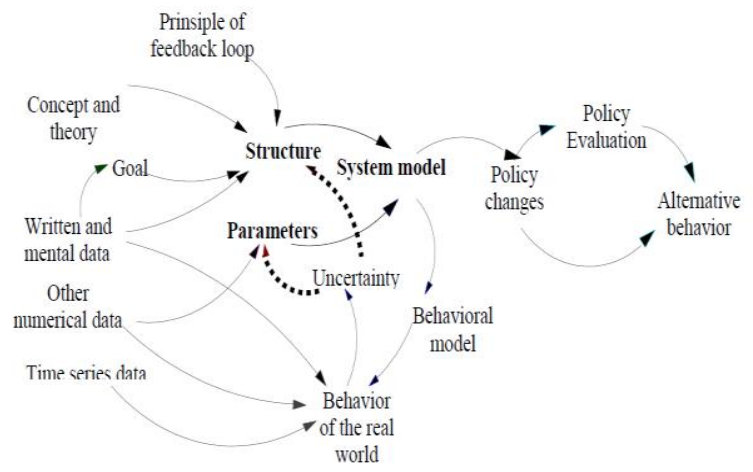

Fig.1. The system dynamics methodology

Developing cassava agribusiness through integrated farming system is a complex and dynamic problem, it encourages to use a systems approach. All entities involved along the cassava supply chain has difference of goal and interests, however, as a system all entities are required to create synergy in achieving their objectives in the whole system of cassava supply chain efficiently and effectively.

The complexity occurs because of the interaction between various agribusinesses from up-stream to down-stream, while the dynamics of cassava agribusiness system reflected changes in behavior over time. Such changes may occur in the product (fresh and processed cassava), facilities and actors along the agribusiness supply chain. Each sub-system is formed from various interrelated components and they form a certain pattern of behavior. It creates complexity between actors and facilities in the agribusiness system.

\subsection{Data Collection}

This research was done in Trenggalek District, East Java Province, Indonesia. It used secondary data, and supported by primary one. Modeling and policy scenario used system dynamics approach and supported by software of Vensim DSS.

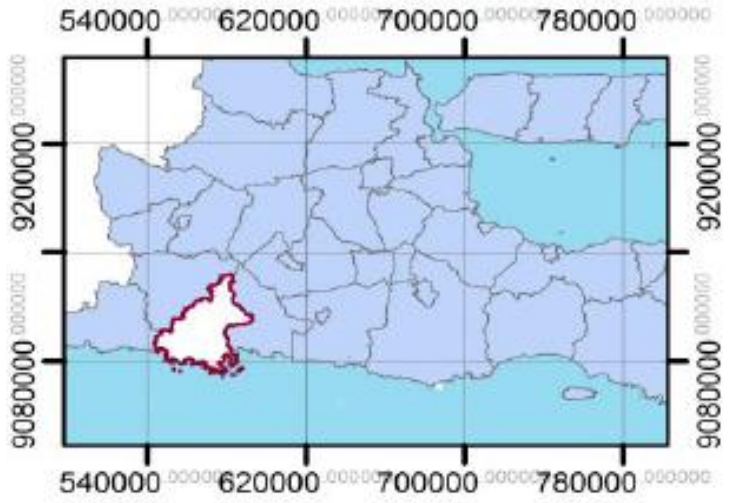

Fig.2. Trenggalek District in East Java Province, Indonesia

Simulation of model behavior used historical data of cassava production for six years (2007-2012) and forecasting data for the next 20 years. So, the total of simulation was 25 years. The model validation used Theil test. This validation method was done to get the trust to the model.

\subsection{Data Analysis}

Numerical data, written information and mental model that has been collected is processed into the model design by using system dynamics methodology. Completion of the model used software of Vensim DSS from Ventana Simulation. The software was used to make: causal loop diagram, model's flow diagram and sub-model (level and rate) of the studied system. The steps are: developing system model, model validation and simulation. The flow of modeling system dynamics is illustrated in Figure 1.

Figure 1 shows the work of system dynamics methodology in developing the model. Parameter (physical and decision structure) in a system dynamics model was developed from secondary data, observation and interviews. Data of mental model, numeric, and written information are constructed by following the principles of feedback loop. Furthermore, the model is simulated based on several scenarios that compare the behaviors of real-world and system model. The scenarios are done based on the changing of parameters in the system model. Based on the simulation results we can give alternative policy recommendation to improve performance of cassava agribusiness.

Stages in designing the model are: (1) problems articulation, (2) model conceptualization and hypothesis formulation, (3) formulation of simulated models, (4) verification and validation, (5) model evaluation and policy design. Moreover, some test for the model involves: (1) model boundary adequacy, (2) structure assessment, (3) dimensional consistency, (4) parameter assessment, (5) extreme conditions, (6) integration error, (7) statistical test for behavior reproduction, (8) behavior anomaly, (9) surprise behavior, (10) sensitivity analysis, and (11) system improvement. This paper presents only the statistical test (number seven).

\subsection{Model Verification and Validation}

Verification is conducted to test the consistency of the created model. The test was done by checking the variable's dimension and determining the accuracy of the selected time step. Moreover validation was performed to check whether the created model is similar with those of the real system. Validation was tested by checking the internal consistency, correspondence and representations (Simatupang, 2000). 
The model validation is presented in two ways, namely statistical and graphical. The statistical test of Theil's Inequality Coefficient (U) aims to see the ability of the model by comparing the behavior of the model simulation results with the system in the real world (historical data). This is done by using the mean square error (MSE) for measuring the error of system behavior from the simulation and the difference from the real-world.

According to Sterman (1984), Theil's Inequality Coefficient (U) categorizes two kinds of errors, that is systematic and unsystematic errors. Systematic error risks to be rejected, while unsystematic error risks to be accepted. Meanwhile, graphical test is done by comparing the graphs pattern from the simulation result and the historical data.

\section{RESULT AND DISCUSSION}

\subsection{Result of Behavior Reproduction Test}

This test was done to know the model's ability to produce the appropriate behavior of system model with the real-world one. Both statistical and graphical test shows unsystematic error (Table 1 and Figure 3).

Table 1. Result of Theil test of the model

\begin{tabular}{|c|c|c|c|}
\hline $\begin{array}{c}\text { Validation } \\
\text { criteria }\end{array}$ & Value & Valid criteria & Decision \\
\hline $\begin{array}{c}\text { correlation } \\
(\mathrm{r})\end{array}$ & 0.978 & $0.9-1.0$ & $\begin{array}{c}\text { High } \\
\text { correlation }\end{array}$ \\
\hline RMSPE & 0.008 & $<0.2$ & Small error \\
\hline $\mathrm{U}^{\mathrm{M}}$ & 0.183 & Close to zero & \multirow{2}{*}{$\begin{array}{c}\text { Unsystematic } \\
\text { error }\end{array}$} \\
\cline { 1 - 3 } $\mathrm{U}^{\mathrm{S}}$ & 0.063 & Small & \\
\hline $\mathrm{U}^{\mathrm{C}}$ & 0.837 & Big & \multicolumn{3}{|c|}{ Final result: the model is valid } \\
\cline { 1 - 2 } & \multicolumn{3}{|c}{} \\
\hline
\end{tabular}

The Theil test shows the validity of the created model. The correlation ( $\mathrm{r}$ ) shows that the historical and simulated data have high correlation. Also the value of RMSPE (Root Mean Square Percent Error) indicates a small error of the system behavior, comparing with those of the real world. The next, all of $U$ values indicate that the model is valid. The bias proportion value limits to nul, proportion variance is small, and proportion covariance component is high. Those statistical values indicate that the model could be accepted.

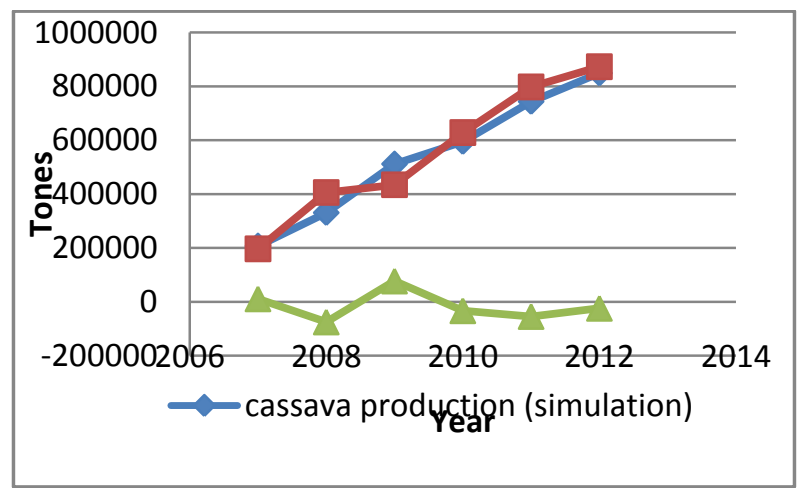

Fig. 3. Theil test result: simulated and historical production

Figure 3 shows the graph that presents comparison between the behavior of cassava production generated from the system model and the behavior of those of historical data. As stated by Sterman (1984) that the system dynamics model is a behavior prediction, is not a point one. Therefore, such graphical performance implies that the model is adequate.

\subsection{Scenario and The Impact}

The scenario is done by adding the structure or changing the rule in using manure in the sub model of cassava production. In Figure 4, the added structure to the model is written in blue. The scenario was a policy of technology innovation namely optimal production with the environmental awareness. The purpose of this policy scenario is to reduce chemical fertilizer cost through the implementation of cassava-goat integrated farming system.

The optimal technology production of cassava with environmental awareness is a technology package which is environmentally friendly and it is adapted to the local specific. It has been recommended by The Research Center for Legumes and Tuber Crops (Balitkabi). The technology is an entry point to increase the cassava productivity, includes: superior varieties, qualified seedling, timing of planting, plant population and plant spacing, fertilization, and harvesting (Balitkabi, 2014). This technology has been empirically tested in Lampung Province and it was quite adaptive. The yield of cassava tuber reached up to 60 tons/hectare, while the profit per hectare was Rp 38.46 million; the Benefit/Cost ratio was ranging from 1.33 up to 3.17 . However, the technology needs support from the seedling supply system and the introduction of new superior varieties, and also promotion of environmentally friendly production technologies (Radjit, et al, 2014)

Growth period of cassava ranges from 4 to 10 months after planting. The plant is critical during this period, so an optimum plant maintenance is required in order to obtain high productivity. This is in line with research findings which show that the growth period determines charging of tuber, plants health and similar size, and produce high yield (Ministry of Agriculture, 2012). It was also supported by Pasaribu et al (2009) who found that farmers would achieve high productivity of cassava if they are supported by the capital availability and production technology of crops and soil. More specific, Subandi (2009) indicated that the components of cultivation technology to support development of cassava production, soil conservation and sustainability of production systems are: superior varieties, setting plant population, seedling preparation, land preparation, planting time, weeds control and fertilization. The application of this technology requires the support from the seedling supply and the introduction of new varieties, along with promotion of environmentally friendly production technologies (Radjit et al, 2014)

The consequence of cultivation technology (particularly fertilizer) in the cassava production system is the increasing of farm cost. However, if the scenario of using organic fertilizer (manure) is applied to the IFS of cassava and goats, the fertilizer cost will be cheaper than then the non-IFS farm. If usage of organic fertilizer increases, the cassava farm costs can be saved.

Death of cassava plants affects the growth rate of cassava production. The growth rate of cassava production positively correlated to the need of farm cost. The highest component of cassava farm cost is purchasing fertilizer, it reached $9.93 \%$ (Darwis et al, 2009). It was followed by labor cost: weeding grass of $8.35 \%$, soil tillage and fertilization of $4.72 \%$, pest and disease control 3.8\%, and planting of $2.91 \%$ (Darwis et al, 2009). 
The intensive of cassava cultivation done by farmers affects the rate of production growth, and the consequence is higher farm cost. Therefore, in order to reduce the cassava farm cost, it is necessary to intervene usage of fertilizer so that more efficient. The description of the scenario to intervene usage of organic fertilizer (manure) in the production sub model of IFS is mathematically formulated as follows:

\begin{tabular}{|c|c|}
\hline NOFC & $=(\operatorname{rog} p+r o p p) * f c p p)$. \\
\hline rogp & $=\mathrm{pigp} /$ grot $\ldots .$. \\
\hline ropp & $=$ pipp/prot,,,.. \\
\hline igp & $=$ INTEG (plan-digp-grot) \\
\hline oipp & $=$ INTEG (grow-dipp-age) \\
\hline igp & $=\operatorname{rog} \mathrm{p}^{*} \mathrm{frcg}$ \\
\hline ot & $=\operatorname{rog} p+(\operatorname{repl} 1 / \mathrm{rept}) *$ fogp \\
\hline ipp & $=$ ropp $*$ frcp \\
\hline $\mathrm{cg}$ & $=$ lifegro/tplan \\
\hline ifegro & $=($ tplan-nob $) *$ efecorg \\
\hline rcp & $=$ lifepro $/$ tplan \\
\hline $\begin{array}{l}\text { fepro } \\
\text { here: }\end{array}$ & $=($ tplan-unplan $) *$ efecfer \\
\hline OFC & $=$ need of farm cost $(\mathrm{Rp} / \mathrm{year})$ \\
\hline ogp & $=$ rate of growing plant (plant/year) \\
\hline op & $=$ rate of productive plant (plant/year) \\
\hline p & $=$ farm cost per plant $(\mathrm{Rp} /$ plant $)$ \\
\hline $\mathrm{sp}$ & $=$ plant in growing periode (plant) \\
\hline ot & $=$ growing time (year) \\
\hline pp & $=$ plant in productive period (plant) \\
\hline ot & $=$ productive time $($ year $)$ \\
\hline $\operatorname{lan}$ & $=$ planing $($ plant $/$ year $)$ \\
\hline igp & $=$ death in growing period (plant/year) \\
\hline row & $=$ growth $($ plant $/$ year $)$ \\
\hline ipp & $=$ death in productive time (plant/year) \\
\hline & $=$ aging $($ plant/year $)$ \\
\hline $\mathrm{cg}$ & $=$ fraction of growth plant $(\mathrm{Dmnl}=$ dimensionless $)$ \\
\hline & $=$ replanting (plant) \\
\hline & ng time (year) \\
\hline
\end{tabular}

$$
\begin{array}{ll}
\text { frcp } & =\text { fraction of productive palnt (Dmnl) } \\
\text { lifegro } & =\text { life plants in growing period (plant) } \\
\text { tplan } & =\text { total plant (plant) } \\
\text { nob } & =\text { not optimal bulb (plant) } \\
\text { efecorg } & =\text { efect organic fertilizer on life plants in growing } \\
& \text { period (Dmnl) } \\
\text { lifepro } & =\text { life plants in productive period (plant) } \\
\text { unplan } & =\text { unhealty plant (plant) } \\
\text { efecfer } & =\text { efect of fertilizer on life plants in productive } \\
& \text { period (Dmnl). }
\end{array}
$$

The simulation of scenario (Figure 4) shows that the new structure about usage of organic fertilizer in the cassava cultivation that are integrated with goat raising is quite effective. This is shown by the behavior of decreased farming cost ranging from $27.75 \%$ to $34.36 \%$.

At the farm level, in fact, learning about usage of organic fertilizers (manure) in cassava cultivations that are integrated with raising goats has been done. However, the result has not optimal yet. The field observation result indicates that the cassava harvested area and production in the study area during 2007-2012 has decreased. The average reduction per year of harvested area and yield were $3.38 \%$ and $1.62 \%$ (Diskoperindagtamben, 2012). Although the productivity was increased by $3.36 \%$ per year (Diskoperindagtamben, 2012), however, the growth was still below the national average growth, 4.8\% (Central Bureau of Statistics, 2014). Therefore, the current cassava farming performances in Trenggalek are: production of 473,014.7 tones, harvested area of 17,765 hectare, and productivity of 26.6 tones per ha (Dipertahutbun, 2012).

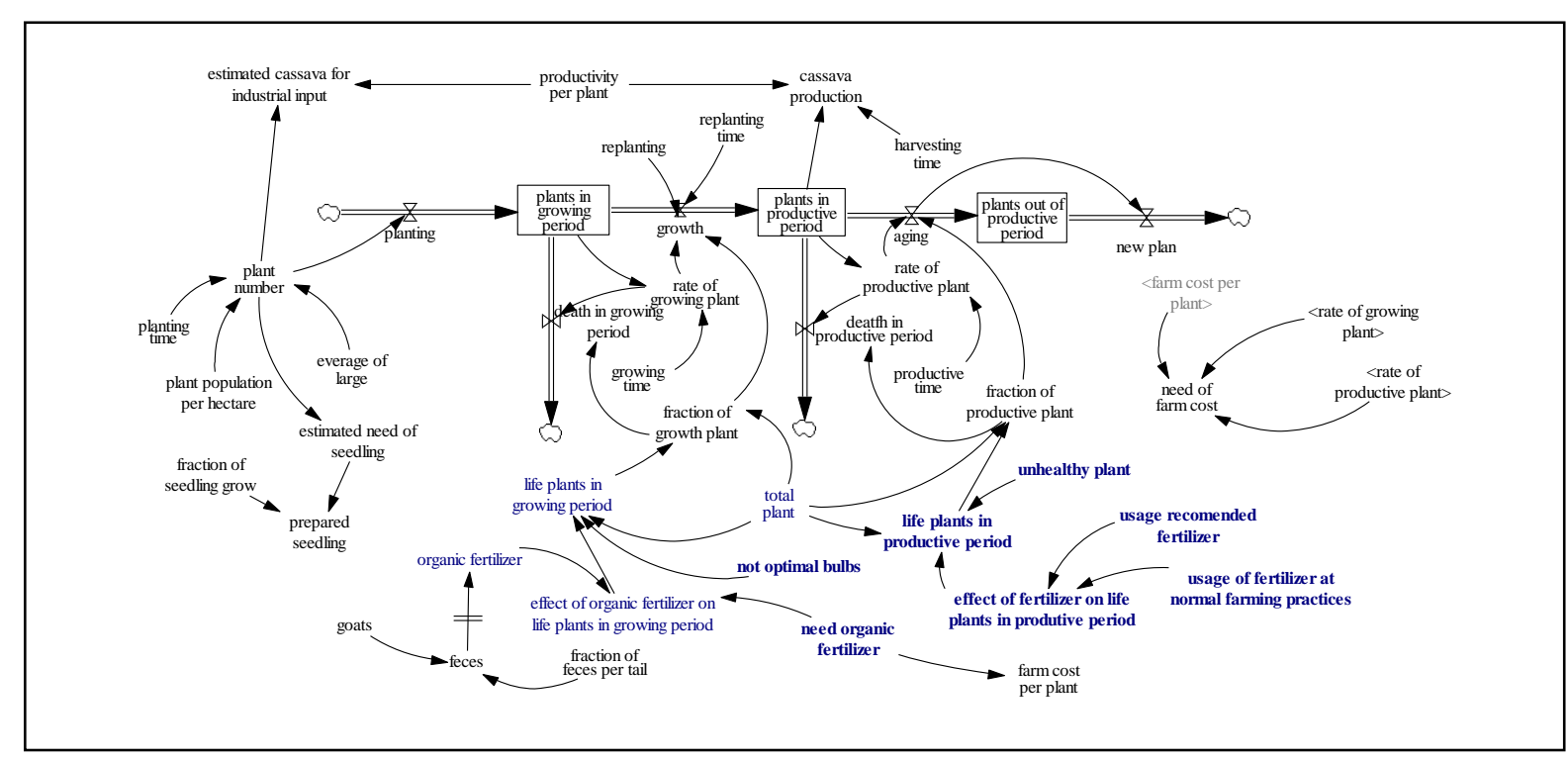

Fig 4: The scenario of changes in the structure of organic fertilizer usage to increase productivity 


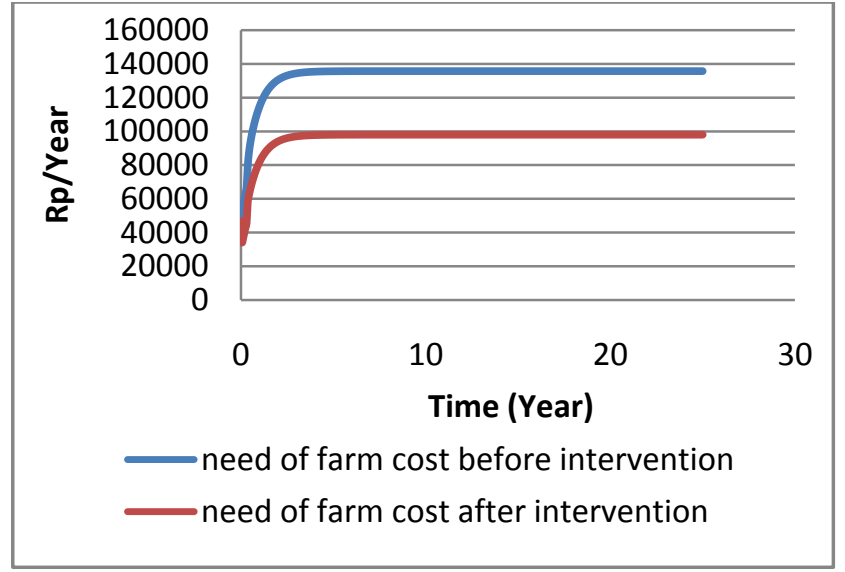

Fig. 5. The impact of organic fertilizer to decrease cassava farm cost

Figure 5 presents the comparison of the needs of farm cost before and after intervention of the scenario in the simulation model. It shows decreasing of those cost with the range from $27.5 \%$ up to $34.36 \%$, as a result of increasing in usage of organic fertilizer. This scenario is applied when farmers implement IFS, focusing on goats and cassava farming.

Table 2. Simulation results of cassava production (tones)

\begin{tabular}{|c|c|c|c|}
\hline Year & $\begin{array}{c}\text { Most-likely } \\
\text { simulation } \\
\text { data }\end{array}$ & $\begin{array}{c}\text { Pessimistic } \\
\text { simulation } \\
\text { data }\end{array}$ & $\begin{array}{c}\text { Optimistic } \\
\text { simulation } \\
\text { data }\end{array}$ \\
\hline 0 & 107,581 & 137,746 & 332,098 \\
\hline 1 & 59,907 & 76,705 & 184,931 \\
\hline 2 & 149,173 & 191,000 & 485,497 \\
\hline 3 & 234,704 & 302,429 & 886,105 \\
\hline 4 & 341,546 & 482,493 & $1,234,210$ \\
\hline 5 & 486,727 & 637,554 & $1,559,140$ \\
\hline \multicolumn{4}{|l|}{$\ldots}$. \\
\hline 11 & $1,115,020$ & $1,427,670$ & $3,442,030$ \\
\hline 12 & $1,216,390$ & $1,557,460$ & $3,754,950$ \\
\hline 13 & $1,317,760$ & $1,687,250$ & $4,067,860$ \\
\hline 14 & $1,419,130$ & $1,817,040$ & $4,380,770$ \\
\hline 15 & $1,520,490$ & $1,946,830$ & $4,693,690$ \\
\hline \multicolumn{4}{|l|}{$\ldots}$. \\
\hline 21 & $2,128,690$ & $2,725,560$ & $6,571,160$ \\
\hline 22 & $2,230,050$ & $2,855,350$ & $6,884,070$ \\
\hline 23 & $2,331,420$ & $2,985,140$ & $7,196,980$ \\
\hline 24 & $2,432,790$ & $3,114,930$ & $7,509,900$ \\
\hline 25 & $2,534,150$ & $3,244,720$ & $7,822,810$ \\
\hline
\end{tabular}

Table 2 presents the simulation result of cassava production that is integrated with goats livestock. The simulation was done based on the historic data (2007-2012) which were presented as year of 0 up to 5 . The simulated production of cassava was estimated for the next 20 years (year of 6-25). The simulation was done for three level of optimism condition (most-likely, pessimistic and optimistic). In this paper we only present some of the result (years 11-15 and 21-25) for saving the table space. All estimated performance, cassava production and farming cost, are presented based on the pessimistic condition to avoid an over expectation.

Although the local wisdom of social values that encourage the adoption of integrated farming has developed in the community, but there are several factors that cause usage of organic fertilizer is not optimal in cassava production systems. The causes are limited knowledge to utilize waste of cassava crop and goats as resources. Famers also assume that composting process of waste requires energy, time, and additional costs. Therefore, introducing the technology needs to be supported by availability of facilities and infrastructure of processing technology of organic fertilizer. It needs support in the form of attention and participation with harmony and mutual need from all stakeholders, government and society, as well as public and private sectors.

\section{CONCLUSION}

Modeling with system dynamics approach is effective to create a complex model of IFS, because the model behavior is similar with those of the real-world. The model also could be used to simulate policy scenarios and estimate the future performance of the model.

The scenario done was a policy of technology innovation namely optimal production with the environmental awareness. This scenario focuses on using organic fertilizer in cassavagoats integrated farming; it is quite effective and can decrease farming cost as much as $27.75 \%$ up to $34.36 \%$.

The scenario needs introduction of composting technology and availability of the facilities and infrastructure. Therefore, the implementation needs supports from stakeholder, i.e. government and society, as well as public and private sectors.

\section{ACKNOWLEDGMENTS}

The authors acknowledge the constructive comments from reviewers. Also our thanks to Kemenristek Dikti, Republic of Indonesia, for the funding of doctoral dissertation research.

\section{REFERENCES}

[1] Agbonlahor, M. U., Aromolaran, A. B., \& Aiboni, V.I, V. I. 2003. Sustainable Soil Management Practices in Small Farms of Southern Nigeria: A poultry-food Crop Integrated Farming Approach. Journal of Sustainable Agriculture, 22(4), 51-62.

[2] Angerhofer, B. J., \& Angelides, M. C. 2000. System Dynamics Modelling in Supply Chain Management: Research Review. In Proceedings of the 2000 Winter Simulation Conference (pp. 342-351)

[3] Anim, F. D. K., \& Mandleni, B. 2011. Factors and risks associated with integrated, conventional and sustainable agribusiness farming. African Journal of Business Management, 5(4), 1124-1128.

[4] Ariadi, B.Y., Karmana, M.H., Rochdiani, D., and Rasmikayati, E. 2014. Model Manajemen Usahatani Dinamik untuk KInerja Petani Ubi Kayu. Jurnal Agraris 1(1), 32-40.

[5] Ariani, M. 2010. Analisis Konsumsi Pangan Tingkat Masyarakat Mendukung Pencapaian Diversifikasi Pangan. Gizi Indon, 33(1), 20-28. 
[6] Awoyinka, Y. A. 2009. Cassava Marketing: Option for Sustainable Agricultural Development in Nigeria. Ozean Journal of Applied Science, 2(2).

[7] Balitkabi. 2014. Cassava Cultivation Technology to Reach Optimum Production (Teknologi Budidaya Ubi Kayu untuk Mencapai Produksi Optimal). Research Centers for Legumes and Tubers in Malang, East Java Province, Indonesia.

[8] Barisa, A. et al. 2015. Future biodiesel policy designs and consumption patterns in Latvia: a system dynamics model. Journal of Cleaner Production, 88, pp.71-82.

[9] Central Bureau of Statistics. 2014. Harvest Area, Productivity and Production of Cassava in Indonesia (2000-2014). Central Bureau of Statistics, Republic of Indonesia

[10] Château, P. et al. 2015. Integrated assessment of sustainable marine cage culture through system dynamics modeling. Ecological Modelling, 299, pp.140-146.

[11] Darwis, V., Muslim, C., \& Askin, A. 2009. Usahatani dan Pemasaran Ubi Kayu Serta Teknologi Pengolahan Tapioka di Kabupaten Pati Provinsi Jawa Tengah. In Seminar Proceding: Peningkatan Daya Saing Agribisnis Berorientasi Kesejahteraan Petani. Pusat Analisis Sosial Ekonomi dan Kebijakan Pertanian. Bogor, Indonesia.

[12] Dipertahutbun, 2012. The Annual Report 2012. Bureau of Agriculture, Forestry and Plantation of Trenggalek District.

[13] Diskoperindagtamben, 2012. The Annual Report 2012. Bureau of Cooperative, Industrial, Trade, Mine, and Energy of Trenggalek District.

[14] Lane, D. C., Schwaninger, M. 2008. Theory Building with System Dynamics: Topic and Research Contributions. Systems Research and Behavioral Science, (25), 439-445. doi:10.1002/sres

[15] Li, F. J., Dong, S. C., \& Li, F. 2012. A system dynamics model for analyzing the eco-agriculture system with policy recommendations. Ecological Modeling, 227, 3445. doi:10.1016/j.ecolmodel.2011.12.005

[16] Mamun, S. Al, Nusrat, F. \& Debi, M.R. 2011. Integrated Farming System:Prospects in Bangladesh. 4(2), 127-136.

[17] Ministry of Agriculture (Kementerian Pertanian Republik Indonesia). 2012. Technical Guidance of Cassava Production.

[18] Muslih. 2008. Membaca: Filsafat Ilmu Asumsi Dasar Proses Kelimuan. Fifth Edition, Yogyakarta.

[19] Okigbo, 1995. Major Farming Systems of The Lowland Savanna of SSA and The Potential for Improvement. In Proceedings of the IITA/FAO workshop, Nigeria.

[20] Olaide, J. 2011. The Structure and Determinants of Land-use Intensity among Food Crop Farmers in Southwestern Nigeria. Journal of Agricultural Science, 3(1), 194-205.

[21] Pasaribu, S. M., Sayaka, B., \& Hestina, J. 2009. Kelayakan Usahatani Skala Keluarga Petani. In Seminar Proceding: Hasil Penelitian Tanaman Aneka Kacang dan Umbi tahun 2012 (pp. 351-363). Puslitbangtan Bogor.

[22] Paucar-Caceres \& Rodriguez-Ulloa.2006. An application of Soft Systems Dynamics Methodology. Journal of the Operational Research Society, 58(6), 701-713.
[23] Paz, K. \& Kljajic, M. 2013. The dynamic simulation of organic farming development scenarios - A case study in Slovenia, 96, pp.163-172.

[24] Piewthongngam, K. \& Vijitnopparat, P. 2014. System dynamics modelling of an integrated pig production supply chain. Biosystems Engineering, 127, pp.24-40.

[25] Pruyt, E. 2006. What is System Dynamics? A Paradigmatic Inquiry Structure. Vrije Universiteit Brussel, Business School Solvay Dept. for Maths, OR, Stats and IS for Management Pleinlaan 2, 1050 Brussels, Belgium.

[26] Rachman, B., Supriyati, \& Supena. 2009. Ekonomi Kelembagaan Sistem Usahatani Padi di Indonesia. Pusat Penelitian Sosial Ekonomi Pertanian, Bogor, 1-10.

[27] Radhammani, S., Balasubramanian, A., Ramamoorthy, K., \& Geethalakshmi, V. 2003. Sustainable Integrated Farming Systems for Dry Lands: A review. Agricultural Reviews, 24, 204-210

[28] Radjit, B. S., Widodo, Y., Saleh, N., \& Prasetiaswati, N. 2014. Teknologi untuk Meningkatkan Produktivitas dan Keuntungan Usahatani Ubikayu di Lahan Kering Ultisol. IPTEK Tanaman Pangan, 9(1), 51-62.

[29] Sebagai Pengganti Konsumsi Beras Untuk Mencukupi Kebutuhan Pangan (Studi Kasus Jawa Timur). Jurnal Teknik Pomits, 1(1), 1-5.

[30] Sari, K., Suryani, E., Prasetianto, R. 2012. Analisa Harga dan Pemasaran untuk Meningkatkan Profitabilitas UKM Kerajinan Kulit dengan Sistem Dinamik (Studi Kasus: Dwi Jaya Abadi Tanggulangin Sidoarjo). Jurnal Teknik ITS, 1(1), 294-298.

[31] Senge, P. M., \& Sterman, J. D. 1990. Systems Thinking and Organizational Learning: Acting Locally and Thinking Globally in the Organization of the Future. In The Conference on Transforming Organizations ( $\mathrm{pp}$. 1007-1022). Sloan School of Management, Massachusetts Intitue of Technology Cambridge.

[32] Senthilvel, T., Latha, K.R. \& Gopalasamy, N. 1998. Farming system approach for sustainable yield and income under rainfed vertisols. Madras Agricultural Journal, 85, pp.65-67 ST.

[33] Shi, T. \& Gill, R. 2005. Developing effective policies for the sustainable development of ecological agriculture in China: the case study of Jinshan County with a systems dynamics model B. , 53 (October 2004), pp.223-246.

[34] Simatupang, T. M. 2000. System Modeling (Pemodelan Sistem). Nindika, Klaten, Indonesia.

[35] Sterman, J. D. 1998. Modeling The Formation of Expectations: The History of Energy Demand Forecasts. International Journal of Forecasting, 4(2), 243-259.

[36] Sterman, J. D. 2000. Business Dyanamics: Systems Thinking and Modeling for a Complex World. (S. J. Senberg, Ed.). Jeffrey J. Shelstad.

[37] Wargiono, J., \& Sudaryanto, B. 2005. Cassava Leaves and Forage Crops for Ruminant Feed in The Establishment of Sustainable Cassava Farming Systems in Indonesia. cgiar.org

[38] Williams, B. \& Harris, B. 2005. System Dynamics Methodology (June), pp.1-16.

[39] Yuhono, J.T. 2007. Sistem Agribisnis Lada dan Strategi Pengembangannya. Jurnal Litbang Pertanian, 26(2), pp.76-81. 